\title{
5. Behind the Fiji censorship: A comparative media regulatory case study as a prelude to the Easter putsch
}

\section{ABSTRACI}

On 10 April 2009, a military backed regime wrested total control of the Fiji Islands in what was arguably a fifth coup and imposed martial law. The then President, Ratu Josefa Iloilo, abrogated the 1997 Constitution and dismissed the judiciary in response to a Court of Appeal ruling - by a bench of three Australian judges - that the interim government of Commodore Voreqe Bainimarama established after the fourth coup in December 2006 was illegal. Bainimarama was reinstated, emergency regulations-including state censorship_-were decreed and elections were deferred until 2014. Earlier, in the first five months of 2008, two expatriate publishers of the leading daily newspapers, the Murdoch-owned Fiji Times and the local Fiji Sun, were deported amid an international furore. In January 2009, a second Fiji Times publisher was expelled. Other journalists have been detained, threatened and harassed. Ironically, the military imposed censorship in the Easter putsch followed two reviews of Fiji's self-regulatory mechanisms in an attempt to strengthen the media landscape. One controversial report has since been used by the military regime as a justification for a plan to consolidate all existing media laws under a single 'Media Promulgation' law. During a parallel time frame, the New Zealand Press Council also conducted an independent review. With reference to the media accountability systems $\left(\mathrm{M}^{*} \mathrm{~A} * \mathrm{~S}\right)$ model developed by the late Claude-Jean Bertrand, this article analyses the public right to know discourse in Fiji in the context of an authoritarian regime.

Keywords: censorship, Fiji, press freedom, media accountability systems 
TN ALMOST four decades of independence, Fiji has faced the paradox of a traditionally free press and a succession of mostly authoritarian or paternalistic governments, whether elected or installed as the result of coups. Currently, Fiji is ruled by a military-backed regime that usurped power following the South Pacific country's fourth coup on 5 December 2006 (Fraenkel \& Firth, 2007; Ratuva, 2008). Almost two years later, the Fiji High Court ruled that the coup was 'not illegal' in a controversial judgment on 9 October 2008 (Qarase and others, 2008). In the first five months of 2008, two expatriate publishers of the leading daily newspapers, the Murdoch-owned Fiji Times and the local Fiji Sun, were deported amid international controversy. ${ }^{1}$ In January 2009, a second Fiji Times publisher was expelled. Other journalists have been detained, threatened and harassed (Karlekar \& Marchant, 2008; Reporters sans frontières, 2008).

On 10 April 2009, a military backed regime wrested total control of Fiji in what was arguably a fifth coup and then imposed martial law. The ailing President, Ratu Josefa Iloilo, abrogated the 1997 Constitution and dismissed the judiciary in response to the Court of Appeal ruling - by a bench of three Australian judges - that the interim government of Commodore Voreqe Bainimarama, established after the fourth coup, was illegal. Bainimarama was reinstated, emergency regulations - including state censorship - were decreed and elections were deferred until 2014 (Robie, 2009).

Two years earlier, in 2007, a Fiji-born consultant, Dr James Anthony, was engaged by the Fiji Human Rights Commission to prepare a report on the 'freedom and independence of the media' in Fiji. This review process was largely rejected by the Fiji news media but supported by some critics seeking greater fairness and balance (Fiji Television Ltd, 2007; Fiji Times Ltd, 2007; Fiji Sun, 2007, Singh, S., 2008, Tarte, 2007). The report also embroiled two New Zealand journalists. ${ }^{2}$ The consultant's report has since been used by the regime as a justification for a plan to consolidate all existing media laws under the 1997 Constitution, the Public Order Act and the Media Council Code of Ethics into a separate 'Media Promulgation' law, at some future point after censorship is eventually lifted (Fiji government media release, 17 July 2008).

During a parallel time frame, in 2007, the New Zealand Press Council engaged two consultants to conduct an independent review of the activities and operations of the council, recommending a higher profile for its role in promoting freedom of expression through responsible media and high editorial 
standards. This was the first independent review since the NZ Press Council was established in 1972 and is regarded by some as a milestone in the public right to know. With reference to the media accountability systems $\left(\mathrm{M}^{*} \mathrm{~A}^{*} \mathrm{~S}\right)$ model of the late Claude-Jean Bertrand as an alternative to self-regulation without government intervention (Table 1), ${ }^{3}$ this article examines and contrasts the public discourse and media consultation processes involved with two media self-regulatory bodies in an authoritarian regime and a democratic government context (see Bertrand, 2002, 2003, 2005; Bromley, 2003; Dadge, 2005; Field, 2007; Pearson, 2007; Robie, 2003, 2004, 2005; Singh, 2005): 'The problem is not, as some in [the Pacific] seem to fear, that government can turn [press councils] into statutory control machines ... the problem is that they have rarely acquired much influence' (Bertrand, 2005, p. 6; Robie, 2008).

\section{Political economy context}

In New Zealand, media freedom is not guaranteed by any supreme constitutional law as it is in countries such as Sweden and the United States. In Fiji, media freedom was even more tenuous due to the impact of four coups or attempted putsches in the past two decades. Both countries have evolved selfregulatory media accountability systems in response to government threats of regulation, more perceived than real in the case of New Zealand.

In Fiji, a few years after independence in 1970, a self-regulatory body called the Fiji Press Council was developed and modelled loosely on the Australian and New Zealand press councils. But the Fiji Press Council 'proved ineffective in its principal task of dealing with complaints against the press' (Morgan \& Thomas, 1996, p. 10) and was reformed and 'reinvigorated' as the Fiji News Council. In 1996, Thomson Foundation consultants Kenneth Morgan and John Prescott Thomas were commissioned by the Fiji government to conduct a review of broadcasting and other laws - such as the Official Secrets Act, the Newspapers Registration Act and Defamation Act - to consider whether statutory regulation should be introduced and to consider how the News Council could 'enhance its independence, public credibility and effectiveness' in dealing with public complaints against the media (Morgan \& Thomas, 1996, p. 31; Singh, S., 2005, p. 48). Morgan had been a director of the British Press Council, and its successor, the Press Complaints Commission, for 12 years and he had been a trustee of Reuters since 1984. Thomas ran a private consultancy, JPT Media Associates Ltd, and had previously been 
Table 1: $M * A * S$ systems in five Pacific countries

\begin{tabular}{|c|c|c|c|c|c|}
\hline Internal $M^{*} A^{*} S$ & $\mathrm{Fiji}$ & Samoa & Solomons & Tonga & Vanuatu \\
\hline Correction box & $\sqrt{ }$ & $\sqrt{ }$ & $\sqrt{ }$ & $\sqrt{ }$ & $\sqrt{ }$ \\
\hline Media reporter & - & - & - & - & - \\
\hline In-house critic & - & - & - & - & - \\
\hline Disciplinary committee & - & - & - & - & - \\
\hline Media page/program & - & - & - & - & - \\
\hline Internal memo & - & - & - & - & - \\
\hline Code of ethics & $\sqrt{ }$ & $\sqrt{ }$ & $\sqrt{ }$ & $\sqrt{ }$ & $\sqrt{ }$ \\
\hline Ethical audit & - & - & - & - & - \\
\hline Ethics coach & - & - & - & - & - \\
\hline Ombudsman & - & - & - & - & - \\
\hline Opinion survey & - & - & - & - & - \\
\hline Company of journalists & - & - & - & - & - \\
\hline External $M^{*} A^{*} S$ & Fiji & Samoa & Solomons & Tonga & Vanuatu \\
\hline Journalism review & $\sqrt{ }$ & $\sqrt{ }$ & $\sqrt{ }$ & $\sqrt{ }$ & $\sqrt{ }$ \\
\hline Alternative media & $\sqrt{ }$ & $\sqrt{ }$ & $\sqrt{ }$ & $\sqrt{ }$ & $\sqrt{ }$ \\
\hline Critical book/report & $\sqrt{ }$ & $\sqrt{ }$ & $\sqrt{ }$ & $\sqrt{ }$ & $\sqrt{ }$ \\
\hline Public statements & - & - & - & - & - \\
\hline $\begin{array}{l}\text { Media-related NGO or } \\
\text { Foundation }\end{array}$ & $\sqrt{ }$ & $\sqrt{ }$ & $\sqrt{ }$ & $\sqrt{ }$ & $\sqrt{ }$ \\
\hline Media observatory & - & - & - & - & - \\
\hline Non-profit research & - & - & - & - & - \\
\hline Higher education & $\sqrt{ }$ & $\sqrt{ }$ & $\sqrt{ }$ & $\sqrt{ }$ & $\sqrt{ }$ \\
\hline Media at school & - & - & - & - & - \\
\hline Consumer group & - & - & - & - & - \\
\hline $\begin{array}{l}\text { Assoc. of militant } \\
\text { citizens }\end{array}$ & - & - & - & - & - \\
\hline Company of users & - & - & - & - & - \\
\hline Public broadcasting & $\sqrt{ }$ & $\checkmark$ & $\sqrt{ }$ & $\sqrt{ }$ & $\sqrt{ }$ \\
\hline Regulatory agency & - & - & - & - & - \\
\hline Cooperative $M^{*} A^{*} S$ & $\mathrm{Fiji}$ & Samoa & Solomons & Tonga & Vanuatu \\
\hline Letters to the editor & $\sqrt{ }$ & $\sqrt{ }$ & $\sqrt{ }$ & $\checkmark$ & $\sqrt{ }$ \\
\hline Public access & - & - & - & - & - \\
\hline Paid-for opinion page & $\sqrt{ }$ & $\sqrt{ }$ & $\sqrt{ }$ & $\sqrt{ }$ & $\sqrt{ }$ \\
\hline $\begin{array}{l}\text { Accuracy and fairness } \\
\text { questionnaire }\end{array}$ & - & - & - & - & - \\
\hline Consulting with users & - & - & - & - & - \\
\hline Liaison committee & - & - & - & - & - \\
\hline Local press council & $\sqrt{ }$ & - & $\sqrt{ }$ & $\sqrt{ }$ & - \\
\hline $\begin{array}{l}\text { National/regional press } \\
\text { council }\end{array}$ & $\sqrt{ }$ & $\sqrt{ }$ & $\sqrt{ }$ & $\sqrt{ }$ & $\sqrt{ }$ \\
\hline Continuous education & - & - & - & - & - \\
\hline Movie or TV series & - & - & - & - & - \\
\hline
\end{tabular}

Source: Singh (2005), adapted from Bertrand in Pacific Journalism Review, 11(2), 54. A table of five Pacific countries and their systems of $M^{*} A^{*} S$ - media accountability systems based on the Bertrand model (see Bertrand, 2005; and also 2002, 2003). 
a broadcasting executive with both editorial and management experience at a senior level in the BBC and Independent Television (Morgan \& Thomas, 1996, p. 32).

While the Thomson review found the technical standards of the Fiji news media generally good-'both daily newspapers are well-produced and print quality of the magazines is high' (p. 11) and radio stations had a 'well-developed style and image' while television was limited by 'modest resources' - it was not so flattering about the journalism:

In terms of journalistic standards, however, we encountered some disquiet. Both politicians and lay representatives gave us instances of poorly researched or insensitive reporting and we ourselves remarked on some examples of unbalanced writing. Media managers and editors admitted to us that there were shortcomings in the qualifications and experience of some of their staff. This dilution of expertise appears partly due to the exodus of experienced talent which followed the 1987 coup[s]. (Morgan \& Thomas, 1996, p. 11)

The Thomson team regarded this problem as a major obstacle to a 'responsible implementation of the proper freedom of the media'. Morgan and Thomas added that 'the effects are still felt as a missing half-generation of trained, experienced professionals to fill senior editorial and "long-stop" subeditorial posts, to act as role models for younger journalists and to provide on-the-job training for new entrants' (p. 12).

Among its recommendations, the Thomson report called for the Newspapers Registration Act to be retained with a clause specifying that registration could not be denied or withdrawn (p.14); the introduction of a new Broadcasting Act covering both radio and television (p. 15); the formation of a self-regulatory Fiji Media Council funded by media industry members and a Media Council Code of Practice (p. 18); the replacement of the Official Secrets Act by an Official Information Act as proposed by Fiji's 1997 Constitutional Review Commission (p. 21); legal barriers to cross-media ownership (p. 23); and media employers, University of the South Pacific and the then Fiji Journalism Institute to 'meet under the aegis ... of the new Media Council to develop an integrated approach to structured on-the-job in-house training' (p. 24).

Two years after the Thomson report, the self-regulatory Fiji Media Council was established by the industry and it also set up an independent complaints 
committee. However, successive governments have accused the Council of being 'incompetent and ineffective' over enforcing ethical guidelines and professional standards (Robie, 2004, p. 54; Singh, S., 2008):

\begin{abstract}
Like similar bodies elsewhere, the Fiji Media Council has been tagged with unflattering labels such as 'toothless tiger' and 'publishers' poodle' by the public and media critics. A common complaint, and not just by leaders, is the council's inability to tackle unbalanced reporting and the media's reluctance to correct mistakes. (Singh, S., 2008)
\end{abstract}

Nevertheless, there have been major achievements by the Fiji news media, such as exposing corruption. An example of this was the media's vigorous investigative reportage of the country's most critical financial issue- 'the collapse of the National Bank of Fiji due to bad and doubtful debts of some FJD220 million (US\$146 million), a staggering 8 percent of Fiji's GDP' (Singh, S. 2008).

In New Zealand, no constitutional or legislative instrument exists comparable to the First Amendment of the United States, which prevents any law curtailing a free press. Yet, it does have some statutes that ensure recognition of the principles of free speech and transparency in democratic government. The Official Information Act 1982 transformed open government in New Zealand, 'prising open doors that had previously been kept firmly shut' (Du Fresne, 2005, p. 24). The Act and a similar local government bill enacted five years later, established the principle that official information should be made available unless there is good reason for withholding it. The Bill of Rights Act 1990 strengthened the right to free speech and the right to know. Section 14 of the Act provides for a general right to exchange ideas and information and shares much of the same wording as Article 19 of the Universal Declaration of Human Rights, which holds that:

[E]veryone has the right to freedom of opinion and expression; that this right includes freedom to hold opinions without interference and to seek, receive and impart information and ideas through any media and regardless of frontiers.

However, the New Zealand media has largely accepted that freedom of the press is balanced by responsibility. The principles of accuracy, fairness and 
balance have traditionally been cornerstones for the New Zealand media. If voluntary compliance fails, a variety of mechanisms exists to ensure these requirements are observed. News media in New Zealand can be held accountable under the Defamation Act for broadcasting or publishing untrue statements that damage people's reputations. They can be charged with contempt of court for subverting the administration of justice. They may also be charged for a breach of privacy, which is emerging as a new tort (Price, 2007). They are subject to Human Rights Act prohibitions on the publication of abusive or insulting speech, and they can be punished by Parliament (even imprisoned, though it has never happened) for abuse of parliamentary rules. Besides these restraints, news media are answerable to self-regulatory bodies such as the Press Council (for newspapers and magazines - and some online publications) and the Broadcasting Standards Authority.

The Press Council was established in 1972 following leaked information that the Labour Party planned to legislate for a statutory regulatory body if it won the 1969 general election (Barker \& Evans, 2007, p. 23). Much of the initiative on setting up a self-regulatory council came from the then New Zealand Journalists' Association (later the NZ Journalists' Union), which had established a Code of Ethics in 1967. However, the Code was not initially supported by the Newspaper Proprietors' Association because it 'cut across newspaper proprietors' prerogatives' (Elsaka, 2004, p. 259).

The foundation Press Council was made up of four members: a retired judge of the Supreme Court (now High Court) as chairman; one representative of the Newspaper Publishers' Association (NPA); one representative of the journalists' union (NZJU); and one representative of the public appointed by the chairman with the approval of the other two members (Barker \& Evans, 2007, p. 25). The Press Council was signed into being on 20 September 1972 with former President of the Court of Appeal, Sir Alfred North, as the first chairman amid ongoing speculation about Labour seeking to create a statutory body. As a later chairman, Sir John Jeffries, described the climate: 'It was self-regulation with a wary eye on the real possibility of statutory intervention' (Jeffries, 2002).

\section{Media and regulatory profiles}

New Zealand:

Four companies, all foreign-owned, dominate the New Zealand news me- 
dia industry, including a "near duopoly in two of the three main mediaprint and radio' (Rosenberg, 2008, p. 176). In television, there is a monopoly in the pay arena (News Corporation-owned Sky TV), and only three significant competitors in free-to-air television, including the state-owned Television New Zealand's two channels. Australian-owned Fairfax Media controls almost half of the country's newspapers (more than 48 percent), including The Dominion Post in Wellington, while the rival APN News and Media(ANM) group — alsoAustralian-owned — controls thelargestcirculation daily, New Zealand Herald and almost 43 percent of the daily newspaper circulation. The main journalists' union (a section of the Engineering, Printing and Manufacturing Union-EPMU) has described the New Zealand media as the 'most concentrated and foreign-dominated' in the world (Rankine et al., 2007).

During 2007, APN 'outsourced' the bulk of the subediting of its titles to the Australian-owned Pagemasters company. In mid-2008, the national news agency, NZ Press Association, downsized and retrenched seven staff while Fairfax Media announced plans to shed 40 editorial jobs and centralise subediting and some specialist news writing into selected centralised nodes for its newspaper chain in a controversial new era of cloned 'hub editors' (Mediawatch, 6 July 2008).

The New Zealand media regulatory model is based on three structures: (1) the New Zealand Press Council (self-regulatory and it adjudicates about 45 print and online media complaints a year); (2) the Broadcasting Standards Authority (BSA), (statutory regulation and deals with about 150 to 250 complaints a year); and (3) the Advertising Standards Authority (ASA) (selfregulatory with 1557 complaints about 493 advertisements in 2006-more than double the number of the previous year) (Barker \& Evans, 2007, p. 12; Ellis, 2005). The Press Council, according to its website (www.presscouncil. org.nz), is the only media regulatory body with a 'free press advocacy role' in New Zealand and it has the smallest budget, approximately NZD\$160,000 a year, funded by the publishers and the EPMU. The only penalty the Press Council can impose is requesting publication of a decision.

The BSA is headed by a barrister or solicitor with not less than seven years' practice in the High Court. While the BSA does not have an advocacy role, according to its website www.bsa.govt.nz it does have a function to conduct research and publish findings on issues relating to broadcast standards. It has 
the power to order a broadcaster to run an approved statement, or to refrain from broadcasting or from broadcasting advertising, or to impose fines, compensation for privacy breaches and costs. Its budget is approximately $\$ 1.2$ million a year with funding provided on a 50/50 split by industry levy and appropriation from Parliament. The ASA has a budget of around $\$ 730,000$ and is funded by advertising levies and subscriptions.

The Press Council membership comprises an independent chairperson unconnected with the media industry appointed by the appointments panel for a five-year term; five people representing the public for four years, appointed by the panel; two members appointed by the Newspaper Publishers' Association (NPA); two members appointed by the journalists' union, EPMU; and a representative of the Magazine Publishers' Association (MPA). Public member vacancies are advertised and appointed by a four-member panel that includes the Chief Ombudsman (Public member appointment, NZ Herald, 2008).

\section{Fiji:}

Fiji has a highly developed media industry (see Figure 1) compared with most other Pacific countries, rivalled only by Papua New Guinea (see Cass, 2004; Robie, 1999; 2004). The largest of the three daily newspapers, The Fiji Times, was founded at Levuka in 1869. More than a century later, it became part of Rupert Murdoch's News Corporation group when the Melbourne Herald and Weekly Times group was taken over in 1987. A consortium of Indo-Fijian importers, C. J. Patel and Co Ltd and Vinod Patel and Co Ltd, and the flagship indigenous Fijian investment company Fijian Holdings Ltd owns the Sun. The paper was launched in September 1999. The Fiji government previously had a controlling 44 per cent interest in the struggling Fiji Daily Post (Robie, 2004, p. 92). While the government retains its stake, minority corporate shareholders Colonial Fiji Ltd and Unit Trusts of Fiji sold their combined share in 2004 to Australian publisher Alan Hickling, who now owns a controlling 51 percent. The South Pacific's largest magazine group, Islands Business International, is based in Fiji. Former Review magazine publisher and entrepreneur Yashwant Gaunder owns the Fijilive.com website, which sprang to international prominence during George Speight's attempted coup in May 2000 (p. 93). Key radio broadcasters are the private Fiji Television Ltd, which also own EMTV in Papua New Guinea; stateowned Fiji Broadcasting Corporation Ltd (FBCL), operator of Radio Fiji; and the private Communications Fiji Ltd (CFL) - the largest radio group in 


\section{Figure 1: The Fiji news media ownership clusters, 2008}

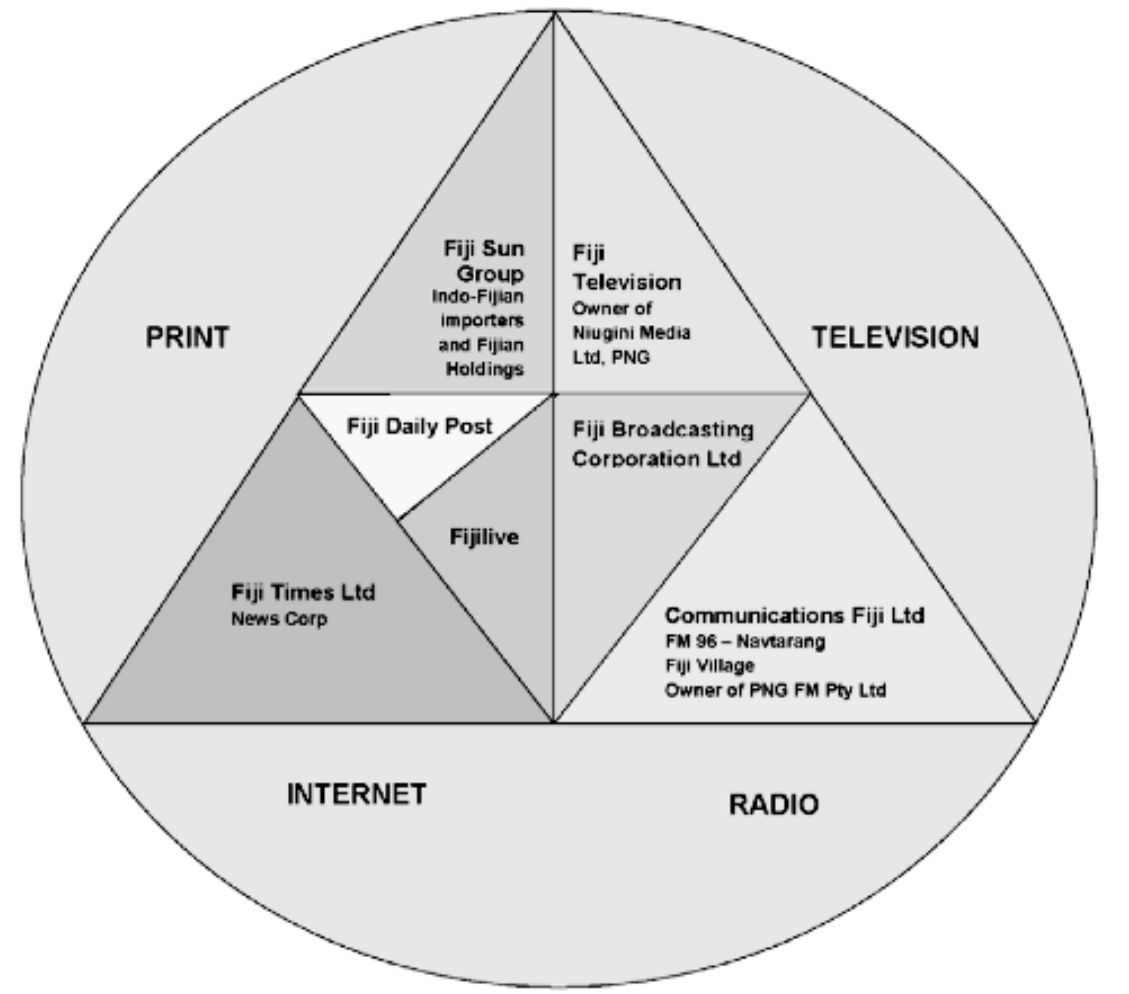

Source: D. Robie and D. Abcede (2008). Only the Fiji Sun still has a majority local ownership, with the shareholdings split between Indo-Fijian importers and traders C. J. Patel and Co. Ltd and Vinod Patel and Co. Ltd and the flagship indigenous investment company Fijian Holdings Ltd; The Fiji Times group also publishes weeklies in the vernacular Fijian and Hindustani languages; and both Fiji Television Ltd and Communications Fiji Ltd have an important media stake in Papua New Guinea, owning EM TV and PNG FM Pty Ltd (Nau FM) respectively, that country's largest broadcasters.

the South Pacific. CFL owns five radio stations in Fiji-including FM96, Navtarang and Radio Legend - and a further two in Papua New Guinea. It also owns the Fijivillage.com portal and internet service provider Unwired Fiji.

Along with Papua New Guinea, Fiji pioneered media self-regulation in the South Pacific island states. The current version is the Fiji Media Council, a registered company representing all forms of media and funded by industry members through biannual subscriptions with a budget of about FJD \$30,000 a year. All eight major media industry groups are members. There are also eight 
public members, an independent chairman and an independent secretary. The Complaints Committee consists of the independent chairman and two public members, who are not members of the Council. They are appointed by the chairman (Singh, S., 2005, p. 49). Although the Council has a website (www.fijimediacouncil.com) with information about its policy, complaints procedures and codes of ethics, this does not provide detailed information about complaints and adjudications. The Council carries out a free press advocacy role and, according to its website, its objectives are to:

- To promote high journalistic standards.

- To enhance the media's image.

- To safeguard the media's independence .

- To uphold freedom of speech and expression.

- To uphold the public's right to be informed accurately and fairly.

- To promote an independent and effective Complaints Committee.

- To promote a Code of Ethics and Practice for journalists and media organisations (Fiji Media Council website, 2008).

\section{Contrasting review methodologies}

Press councils are found in some 87 countries. Many press councils have their own websites, which are a useful source of information and were drawn on by one review (New Zealand) and not the other. Bertrand's $M^{*} A * S$ website (www.media-accountability.org) also provides a range of information. This section of the article examines the comparative methodologies adopted for the contrasting media council reviews in Fiji and New Zealand.

\section{New Zealand:}

The constituent members of the NZ Press Council commissioned Sir Ian Barker, retired senior judge of the High Court, and Dr Lewis Evans, professor of economics and finance at Victoria University of Wellington, to conduct the review in February 2007 (Barker \& Evans, 2007, p. 2). Before retiring in 1997, Sir Ian had served periods as Acting Chief Justice and had presided over several high-profile commercial cases such as the Securitbank litigation and major competition cases such as Kapuni Gas. He sat on various South Pacific Courts of Appeal and was knighted for services to law in 1994. Professor Evans holds a PhD in economics from the University of Wisconsin-Madison. His professional specialty has been in economics of organisations and markets, and he has published widely in academic 
economics journals. In 2005, he was appointed a Distinguished Fellow of the New Zealand Economics Association (ibid., p. 1). A recent law and commerce graduate, Richard Robinson, was appointed secretary to the review. A dedicated website was established for submissions and a separate post office box and premises from the Press Council established (at the Pipitea campus of Victoria University).

The review authors and their credentials were accepted by the industry without much debate. They noted in their report that while constituent members, individual members and the chair of the Press Council made submissions, 'we have acted completely independently of the constituent members and of the Press Council' (Barker \& Evans, 2007, p. 2). They adopted benchmarks of accessibility, independence, fairness, accountability, management and effectiveness used by the Banking Ombudsman Commission for an independent review in 2006. Accessibility was defined as 'readily available to customers' with promotion and no cost barriers. Independence meant the council complaints process was independent of the constituent members. Fairness was based on observing the principles of procedural fairness, by applying specific criteria and giving cogent reasons for decisions. Accountability was defined as publishing its determinations and information about complaints while highlighting any systematic industry problems. Management involved ensuring that complaints were dealt with by an appropriate process or forum and regularly reviewing overall performance. Effectiveness was defined as having an appropriate and comprehensive terms of reference and periodic independent reviews of its performance. The terms of reference of the New Zealand review included the following aims:

1. to review the purposes, activities, performance, governance and resourcing of the New Zealand Press Council;

2. to consider whether the council's objectives are adequate in the light of the changing circumstances and public perceptions and whether the council is operating in a manner consistent with them; and;

3. to assess the range and scope of the council's activities when compared with the operations of similar bodies in other countries (ibid., Appendix 1. p. 85).

The New Zealand review consulted available global websites and wrote to all known press councils, receiving responses from 18 of them-including 
the Fiji Media Council. The review members also met the Australian Press Council in April 2007. This data was documented and tabulated as a comparative survey (ibid., Appendix 4). A survey of the public, organisations, complainants and media organisations was also conducted as part of the review (ibid., Appendix 5). Four surveys were undertaken: (1) individuals and the Press Council (surveyed members of the public, with 147 responses); (2) organisations and the Press Council (surveyed public organisations with 34 responses); (3) complainants to the Press Council (60 responses from 255 complaints drawn from the previous six years); and (4) media organisations and the Press Council (surveyed newspapers and magazines with 18 responses). The findings and recommendations were published in a 192-page report and on the Press Council website. A range of detailed references was cited in the document, including a doctoral thesis on the history of the Press Council (see Elsaka, 2004) and other contemporary international academic research.

\section{Fiji:}

In May 2007, two decades after the original coup in Fiji by third-ranked military officer, Lieutenant-Colonel Sitiveni Rabuka, the media freedom advocacy organisation, Article 19 asked the Fiji Human Rights Commission (FHRC) to 'write a short piece on freedom and independence of the media' (Shameem 2008a, p. 1). Fiji was regarded as more advanced than most Pacific Island states in developing a media accountability system (see Table 2). However, the Commission 'found significant gaps' in information available about media independence and freedom in Fiji, particularly relating to media ownership, media workers, censorship and new technologies. According to FHRC director Dr Shaista Shameem:

An inquiry by an independent consultant, pursued under s 7 of the $\mathrm{Hu}$ man Rights Commission Act, seemed to be the most appropriate way to conduct a study of media freedom and independence, including of issues emanating from the political upheavals of 2000 to 2006. (ibid., p. 1)

In July 2007, the Commission initially appointed former NZ Race Relations Conciliator Gregory Fortuin, who already had some experience of Fiji, having been an elections observer with the Pacific Island Forum Observer Mission during the 2006 general election. However, the proposed inquiry faced a 'hostile reaction from mainstream media' organisations, according to Shameem (ibid.), and Fortuin subsequently withdrew. Chief 
executives of four of the five leading Fiji media groups-Communications Fiji Limited, Fiji Times Limited, Fiji Television Limited and the Sun (Fiji) Limited-wrote to the FHRC, saying they were alarmed at the proposed inquiry and 'took little comfort' from Shameem's foreign 'intervention' report (2007), regarded by the media industry as an apologia for the December 2006 coup (Parkinson et al., 2007, p. 1). The letter declared that the inquiry 'repeats an incursion of a biased FHRC into areas where it could improperly invoke human rights causes to control the media' and refused to participate (ibid., p. 3). This letter was dispatched the day before Fortuin's successor as inquiry consultant, Dr James Anthony, arrived in Fiji. Anthony also faced a critical reception as media organisations were unconvinced over his credentials for such a mission and regarded him as being too controversial. Longtime Fiji journalist Graham Davis penned an article in The Fiji Times that outlined his 'injudicious behaviour ... and pronouncements' (Davis, 2008). These included being an instigator, along with the late Apisai Tora, of an oil workers' strike that erupted into rioting in Suva in December 1959, and allegations that the US Central Intelligence Agency had been behind the 1987 coup (Davis, 2008; Robie, 1989, p. 245).

Although Anthony had lived much of his life in Hawai'i, he was born in Fiji and played a role in the country's politics in the 1960s. His professional background is as a political scientist and a Pacific historian. After gaining his first two degrees at the University of Hawai'i, he completed his doctorate at the Australian National University in 1971. He co-authored a book about the Legislative Council elections of 1963-Fiji's first national political ballotwhich involved some analysis of the Fiji media. He has also said he has been working on a book on Fiji's current politics for the past five years. He has a fluent command of Fiji's three main languages_-English, Fijian and Hindi.

The terms of reference for the Anthony report were to:

1. provide a historical overview of the range of media available in Fiji, including ownership and scope of operations;

2. review international human rights and other laws and policies with respect to freedom and independence of the media and assess Fiji's compliance with them;

3. review whether the Fiji media complied with international standards of corporate responsibility for media freedom and independence;

4. review laws and policies on the right of the public to information; 
PUBLIC RIGHT TO KNOW

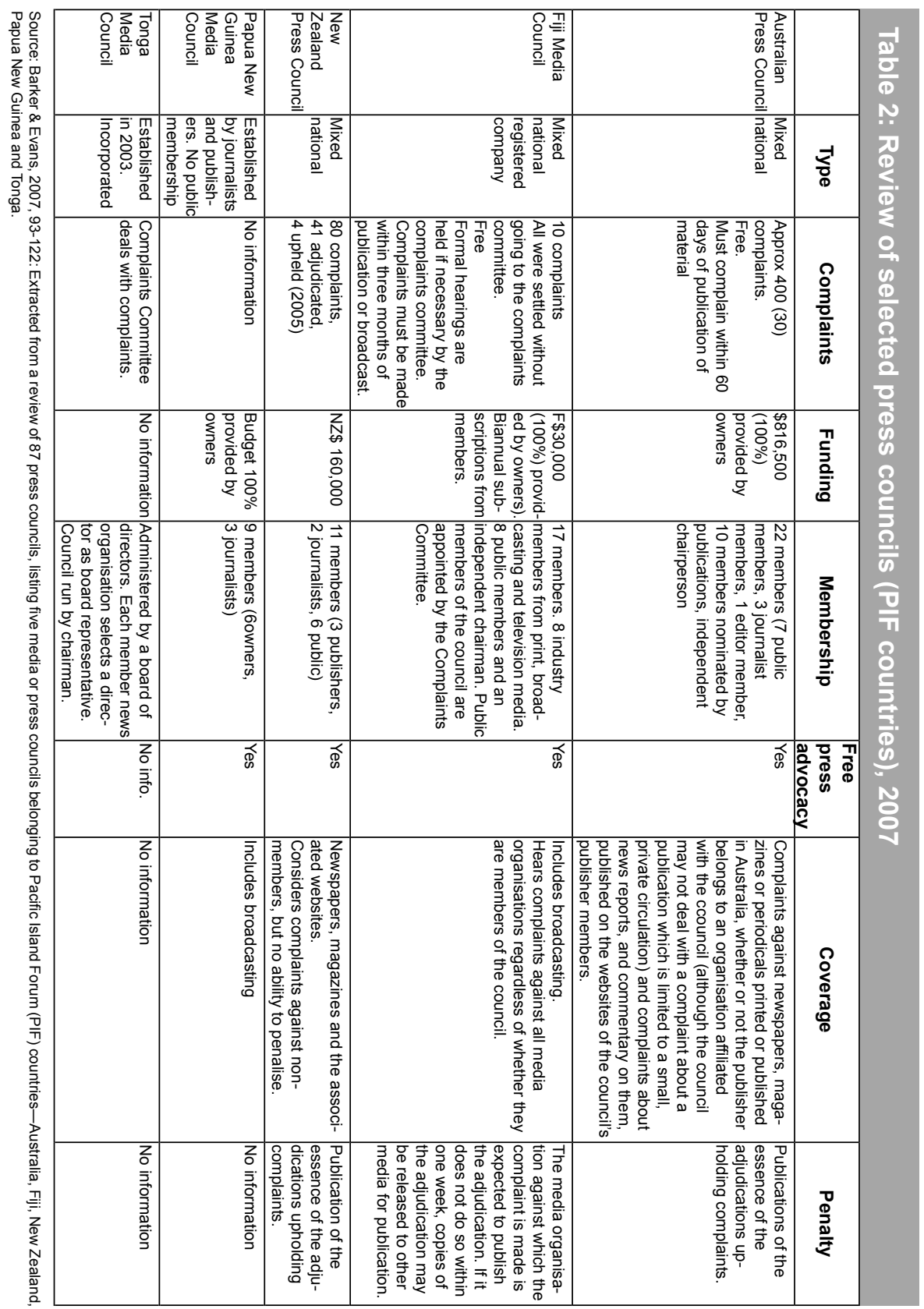


5. review the extent to which the public's right to accurate, balanced and updated information is protected in Fiji;

6. review current systems in place to protect journalists and other media personnel from violations of their rights;

7. review whether work conditions of media personnel comply with constitutional provisions on fair labour relations;

8. review whether journalists have freedom internally and externally to exercise their functions in the public interest to the extent required by international human rights law (FHRC, 2008, Appendix 1, p. 107).

Anthony reviewed an 'extensive repertoire of hard copy information: reports, books, government documents and information' from various sources provided by people he interviewed. He interviewed 61 respondents, using an open-ended methodology and mostly face-to-face over a period of two weeks. The early interviews were said to have been recorded and transcribed by Hansard reporters. All interviewees were given a personal assurance that their identity would remain confidential. Anthony's final 290-page report included substantial appendices presenting critical and hostile responses from the industry to the review process generally and the draft report specifically (65 pages). It also included a 34-page appendix about the controversial Duavata Initiative Limited, an investment company alleged to include five of Fiji's major media companies ${ }^{4}$ - denied by all and described by Fiji Television, for example, as 'defamatory and outrageously silly' (Fiji TV, 2007). Although the document contained three pages of references, few had contemporary relevance to news media in Fiji or recent literature relating to the Fiji Media Council, and research on media accountability in the republic appeared to have been either ignored or overlooked (Robie, 2004, pp. 201-238).

\section{Discussion}

New Zealand:

The New Zealand review was largely uneventful, certainly not controversial and diligently pursued an empirically based research programme while developing a raft of recommendations aimed at making the Press Council more 'robust' (Barker \& Lewis, 2007, p. 84). The surveys and interviews 
produced a 'mixed assessment' (p. 67). While many people and organisations 'maintained that it was doing a good job and its adjudications were fair and balanced', there was a range of specific criticisms. Some submissions indicated a 'fall-off in standards of journalism, with allegations of how badly the press behaved in certain circumstances'.

A summary of several key issues encountered and raised by complainants and the Barker and Evans response includes (see pp. 67-73) that the'Press Council [is] not independent, or perceived to be independent of the publishers' (a view not supported by the survey results), the Council having 'no power to investigate properly or to obtain information' (compared with BSA powers, which includes a statutory right to make investigations and compel disclosure of documents); and the'lack of sanctions'. The review panel called for a graduated scale of penalties: (a) rejected - to apply when the complaint has no chance of being accepted; (b) not upheld - when a publication has behaved properly before and after publication; (c) partially upheld-when the Press Council decides some parts of the complaint are justified but others are not; (d) upheld - when the Press Council decides that a complaint should be upheld but there is no evidence that a publication behaved irresponsibly; and (e) censured - when a complaint is not only upheld, but the Press Council needs to send a 'message of rebuke for a job poorly done' (p. 68).

Also, an'objection to the requirement to sign away legal rights' was examined. According to the review, some 59 percent do not sign the waiver (p. 69). The review panel was informed by the Australian Press Council that nobody had ever tried to institute legal proceedings after having signed. However, the panel also heard 'impressive legal opinion' that such a waiver would be unlikely to be held up by the courts because it 'violates public policy'. There was wide agreement among the submissions that defamation actions are costly, stressful and lead to unsatisfactory outcomes.

The final Barker and Evans recommendations (pp. 4-6) included a call for the Press Council to take an even higher public profile, in addition to its complaints adjudications - not unlike the Fiji Media Council's professed role. The review panel said the Council should: (a) promote freedom of expression through a responsible and independent print media and through adherence to high journalistic and editorial standards; (b) conduct limited research into media freedom issues; (c) sponsor an annual public lecture on a media-related topic and an annual prize at one or more journalism schools; and (d) produce 
occasional papers on media freedom issues. Among other recommendations were that the Press Council should become an independent legal entity; a proposed chief executive should be appointed who would consider all complaints in the first instance and act as 'gatekeeper'; a three-member 'fast track' complaints committee should be established and operate continuously; a graduated scale of penalties should be introduced; a majority of public members should participate in any adjudication; the Council's jurisdiction should be expanded to encompass e-publications; and independent reviews be held every five years.

\section{Fiji:}

The Fiji review was perhaps compromised from the start, given the resistance of the media industry to: (a) the need for a review in the first instance; (b) the appropriateness or otherwise of the Fiji Human Rights Commission conducting the review; (c) the controversial choice of consultant to carry out the review; (d) the adversarial conduct of both the consultant and leading media industry personalities; and (e) the perception of an extreme set of recommendations. The FHRC director, Dr Shameem, drew a parallel with a 2000 inquiry into racism and the media in South Africa for justification to support the Commission's role over the review:

Negative reactions of the media industry to human rights scrutiny in the public interest are not unique to Fiji. Other human rights commissions have faced similar obstacles. For example, in August 2000, the South African Human Rights Commission, which has similar statutory powers as the FHRC, announced an inquiry into racism in the South African media. Its report, Faultines: Inquiry into Racism in the Media, attracted merely 13 submissions (from a population of millions), compared to the 61 responses received in the FHRC's recent inquiry.

What is interesting, though, is that the media industry's reaction to the inquiry of the South African Human Rights Commission was similar to the hostility faced by the FHRC. The media industry in South Africa (as in Fiji) became vituperative and slanderous. Its monopoly over the vehicle of information gave it the power to publish falsehoods, insinnuendos [sic], editorial presumptions, and to blatantly disregard all media codes of conduct and ethics. Clearly there is no real protection available from such attacks from the media industry. In South Africa, the strident objections of the media industry to the South African Human Rights Commission's inquiry into media racism were so obstructive that the 
commission announced its intention to exercise its statutory powers to subpoena members of the industry. (Shameem, 2008a, p. 4)

However, the Fiji media believed strongly that the review was prejudged from the start and that both the FHRC director and the consultant had 'chips on both shoulders' (Davis, 2008). The media generally rejected the review's to be 'independent' and challenged the director's view that 'heaps' of people had come forward to make submissions. The media wanted these people identified, but the Commission had given a guarantee of anonymity. A prevalent view in the media was articulated in a Fiji Sun editorial headed 'Source of mystery' (7 August 2007), which alleged lack of transparency, while rejecting the review terms of reference and challenging the choice of consultant:

All we are told by the commission is that Dr James Anthony has massive experience in the areas of human rights and media. We have deliberately avoided the term 'heaps'.

However, the only specifics we have from the commission are that Dr Anthony led the oil workers strike of 1959 that led to riots that destroyed much of the nation's capital. This, we are assured, gives him some human rights status. Then, it is learned (again from the commission) that he once spent a few months as a spin doctor for an obscure minister for the imploding Whitlam government in Australia.

This, it seems, qualifies him to sit in judgment on the entire media industry of a sovereign nation.

It is known that Dr Anthony is a widely respected academic in the area of cultural studies.

Why he has been chosen to conduct an inquiry into Fiji [media] is something of a mystery.

Unless, of course, genuine media experience and expertise was regarded as a drawback (Fiji Sun, 7 August 2007).

Interestingly, by comparison neither Barker nor Evans had any particular expertise in the media industry when they were selected as consultants for the NZ Press Council review. This did not seem to be considered a drawback by the New Zealand media industry. The tone of the editorial itself paralleled a letter by the Fiji Sun's publisher, Russell Hunter, who wrote to the FHRC, asking: 


\section{PUBLIC RIGHT TO KNOW}

Can we be very clear on this? Is the FHRC really saying that a (very short) stint as a spin doctor for an obscure politician in an imploding government some 30 years ago qualifies Dr Anthony to pronounce and recommend legislation on the entire media industry of a sovereign nation?

And is it also really saying that leading a strike nearly half a century ago gives him some human rights status? I'd appreciate a response as the Fiji Sun intends to comment on this. (Hunter, 2007a)

Dr Anthony referred to alleged efforts to defame him and discredit his qualifications for such an inquiry (FHRC, 2008, pp. 26-27) by saying in the report that he left a message on Hunter's voicemail, asking him to contact him for further information after the FHRC had provided resume data. Shortly after, the Sun published the cited editorial 'attacking my professional qualifications - without any reply from me. I recognised this as part of an old pattern of sleazy journalism' (p. 27). He followed this 'sideshow' with a section on the stand-off with the Fiji media industry:

My view was that [Fiji Media Council chairman Daryl] Tarte had probably realised that he and his colleagues had made a strategic mistake by deciding that they would boycott the inquiry. So now, after the deadline to make submissions had passed, the Fiji Times, Fiji Sun, and possibly others, as well as some members of the Media Council (one or two participated secretly), had launched a media campaign in a vain attempt to discredit the inquiry. The director of the [FHRC], in an effort to be conciliatory, recommended to me that Tarte and his colleagues be allowed to make submissions to me even though the deadlines for receiving submissions had passed and I was more than halfway through writing my report...

Nothing came of Dr Shameem's conciliatory gesture in any event, as there was no response to her offer. Nevertheless, the Fiji Times and the Fiji Sun continued their obscene offensive and I continued to write my report... (FHRC, 2008, p. 28)

According to Anthony, all news media were invited to make submissions to the inquiry in the same manner as the general public: 'They chose not to attend. I will not speculate about their motives' (FHRC, 2008, p. 28). Much of the Fiji news media coverage of the review issue failed to contextualise that there were also several parallel, consultative body initiatives to 
examine the role of the media in Fiji related to the so-called People's Charter (see Fiji State of the Nation Report, 2008; National Task Team 1, n.d.; Moore, 2008). National Task Team 1 on Good Governance said 'there is ... no good reason for the printing section of the Fiji media to be paranoid about regulating laws that are constitutional and designed to strengthen the press media's autonomy' (p. 22). It supported the notion of a statutory Fiji Media Council and a media tribunal with appropriate powers of redress for 'ordinary people' as an alternative to costly defamation cases (p. 24). According to the Fiji State of the Nation Report's section on the media:

In the circumstances which Fiji now faces, when a greater proportion of its population is poor[er] than was the case at the time of Independence, the need for changes that will move the country forward is urgent. For the media to engage on these issues is not to surrender its independence - it should remain sceptical and critical but also forthrightly committed to promoting what it believes is best in the public interest for the development of the country. Often that is what newspapers seek to do through their editorial or opinion pieces.

Unfortunately, this idealistic perspective does not work too well in Fiji. While today there is more analysis and feature writing than in the past, by and large most reporting is straight narrative. Some of it is very superficial. Most of the articles in the daily newspapers that provide more serious analysis and commentary on current issues of governance and other national concerns are written by academics, civil society activists and other professionals and not by journalists. (Fiji State of the Nation Report, 2008, p. 3) [author's emphasis].

Some of the issues about the Media Council, as perceived by the general public and raised in the Anthony inquiry with responses, include (pp. 38-94):

'The industry members appoint themselves': The method of Media Council membership selection in the name of self-regulation 'simply smells' (FHRC, p. 40). The report states that the Ministry of Information nominates its own representative and the chairman appoints this person, and appoints the public members and University of the South Pacific representative. Anthony claimed that such a procedure is 'not designed to generate confidence - not only is it not impartial, it is not even seen to be impartial'. The consultant cited responses describing the Media Council variously as 'a toothless tiger', 'incompetent', 'a white man's club' and 'a farce'. 
'The Complaints Committee lacks legitimacy': According to Anthony, the Media Council complaints process has 'little credibility' with the wider community and is regarded by many as a 'dead letter'. Some people making submissions regarded the failure of the media industry to take part as a 'subterfuge ... to avoid a human rights scrutiny' (p. 43). While the Complaints Committee processes several complaints each year, it is not seen as addressing the 'main problems'. The three members of the Complaints Committee are claimed to be seen as being 'part of the system' (p. 51).

'Gagging of employees': Anthony alleged that senior management of several news media organisations 'gagged' their employees from taking part in the review. He cited examples such as these: a Fiji Television employee said colleagues on the channel were 'under instruction not to speak to the inquiry consultant'; a senior employee of Communications Fiji Ltd had been instructed not to answer any inquiries from the consultant and that all inquiries were to go through the chief executive, William Parkinson; Media Council secretary Bob Pratt had said chairman Daryl Tarte had instructed him not to reply to any requests for information; and Fiji Times executives had called a staff meeting where journalists were told the review terms of reference were not satisfactory and their 'best interests' would be served by not participating in the inquiry (p. 47).

'An ever present problem of line journalists being recruited "on the cheap"': Anthony summarised from submissions to say that journalists did not stay long with media organisations - 'they are under-prepared intellectually, they write poorly'. Journalism becomes a 'way station to somewhere else'something where pay and working conditions are better. The high staff turnover generates problems related to continuity and institutional memory (p. 50).

'There is a marked tendency to misrepresent': According to Anthony, an academic informant said the media did not seem to be non-partisan: 'For example, it has not been neutral to the Fiji Labour Party. Their statements are mangled, misrepresented. The problem, a recurring theme, is at the editorial, subeditorial level. Journalists are lazy, do little research, [and] have little training. They are not paid well.'

Summarised, the conclusions of the Anthony report were:

1. A Media Tribunal should be established in Fiji;

2. The Media Tribunal should be independent of any government control; 
3. A Media Development Authority should be established;

4. The authorities should consider facilitating the enactment of legislation that provides penalties for the publication or broadcast of any material that can incite sedition or that is in breach of the Public Order Act;

5. The FHRC should take necessary steps to recommend to the government a seven percent tax across the board on all media advertising revenue and a further seven per cent on all revenues generated from licence and monthly user fees on consumers; this monies generated to be used to fund all activities and the mission of the Media Tribunal and Media Development Authority;

6. FHRC should take necessary steps to strongly recommend to government that all existing [expatriate] work permits in the media industry not be renewed and that no further work permits be issued; and

7. A second tier of recommendations to government should include scrutiny of 'interlocking directorates' in the private sphere from the perspective of their limitations on democracy.

Fiji media industry leaders bitterly condemned the draft report with written reactions ranging from The Fiji Times' chairman of directors Ross McDonald (2007), who described it in a one-page letter as 'blatantly racial, deeply offensive and insulting and a scurrilous attack on the integrity of both myself and other "whites" in Fiji', to the Fiji Sun publisher Russell Hunter, who condemned it in a lengthy and detailed document as being 'riddled with inaccuracy. It is a long litany of opinion dressed up as fact' (Hunter, 2007b). Other responses included Islands Business managing director Godfrey Scoullar describing the report as 'inciteful and possibly criminally liable', adding: 'Europeans do not run Fiji through the media and from the Media Council "club house", cosy office meetings or house-to-house gatherings.' Fiji-born journalist and commentator Graham Davis, who is now a principal in the Australian company Grubstreet Media, wrote in The Fiji Times when the report was released after the expulsion of Hunter in late February 2008:

One [chip on Anthony's shoulder] is an obsession with race, notably his evident distaste for the 'white man' who[m] he blames for many of the Fiji media's shortcomings. 
The other is his perverse desire to throttle whatever independence the nation's media still has and give the present interim government even more control over the information ordinary people get from their radio, television and newspapers.

How odd that a man who presumably defends the principle of academic freedom should be opposed to media freedom.

And how scandalous that such a document should emerge from the one public body specifically charged with the defence of the rights of all Fiji citizens. (Davis, 2008)

Nevertheless, the FHRC endorsed the Anthony report and referred it to the Fiji interim government, recommending that the two proposed institutions should have separate duties: firstly, the Media Tribunal should be given responsibility for 'expeditious inquisitorial assessment' of allegations against the media and provide a judicial remedy if needed. The statutory tribunal should be empowered to award compensation and damages. Secondly, the Singapore-styled Media Development Authority should be tasked to monitor media organisations and provide training to raise the standard of news reporting in Fiji and to develop cooperation between government and the media.

In July 2008, the interim government announced that all existing media laws relating to the Constitution, the Public Order Act, Media Code of Ethics and professional standards would be incorporated into a separate 'Media Promulgation' (Fiji government media release, 17 July 2008). The draft document was expected to be made public in December (Fiji government media release, 4 November 2008). This never happened and nine months later the Constitution was abrogated and censorship imposed.

Belatedly, the Fiji Media Council initiated its own independent review and this was convened in February 2009. The terms of reference included examining how the Council had 'carried out its responsibilities', its relationship with government, its funding and administration and the complaints process. Nominated as consultants were Australian Press Council executive secretary Jack Herman, Fiji community development advocate Suliana Siwatibau, and retired lawyer Barrie Sweetman, former chairman of the law firm Munro Leys, which acts for The Fiji Times and other media groups.

In their final report, the consultants dismissed the Anthony report as 'chillingly Orwellian in its main theme: he argued that the only way 
to preserve media freedom and independence was to sacrifice them' (Herman et al, 2009, p. 5). While complimenting the Media Council in general terms, the Herman report noted that the Council had not been active enough in pressing for improvements in media standards and that it had 'appeared more frequently to be vocal about the need for media freedom, without a concomitant voice on media responsibility' (ibid., p. 6).

Essentially, in the view of the Review, the Council has been limited by a lack of finance ... [T] he Review recommends that a professional office, staffed at least by an executive secretary on a permanent parttime or fulltime basis, be established...The Review recommends that the Media Council use a graduated scale of findings and orders that will provide it with some teeth. (ibid.)

\section{Conclusion}

In the end, the Fiji Media Council's attempt to establish an independent review was perceived by the regime as too little, too late. Determined to gag the media, the regime deferred a 'promulgation' law, but took the more extreme path of imposed censorship instead. At the time of completing this article, the regime had already extended martial law for three months. Analysts such as the late Claude-Jean Bertrand would have seen a flawed media as being partially responsible for the draconian response, arguing that whatever the 'pompous declarations' about democracy, press freedom, the First Amendment and the Fourth Estate in a globalised world: 'Something is rotten in the realm of media' (Bertrand, 2003, p. 4). Everywhere, including Fiji. Bertrand's writings about media accountability point to an increasing concentration of ownership, public distrust of the media, decreasing sales and ratings and an erosion of ethics and accountability as examples of a widespread malaise. A deregulated media has concentrated on only two of its functions - entertainment and the sale of advertising. The trend in recent years has been to reduce news staff and increase infotainment to attract customers and advertisers-'cheap fun instead of public service'. Bertrand argued that journalistic traditions had lost their way amid the diverse challenges facing the media.

News media often consider forms of $\mathrm{M}^{*} \mathrm{~A} * \mathrm{~S}$ as direct threats to their freedom instead of as an opportunity to improve the quality of journalism and independence. Press freedom is seen as a supreme value instead of a means 
to serve the public interest well. An element of hypocrisy exists about media freedom. While governments are seen as encroaching on media freedom, few journalists acknowledge how media freedom and journalists' autonomy in news organisations is frequently controlled and eroded by corporate managements. Often the media is perceived as being too close to power elites. Ultimately, the Fourth Estate role should be derived as a counter-balance to the sources of power. For this to be credible, the media needs more public accountability.

The contrasting dynamic of two separate reviews of media accountability and the public right to know in two Pacific countries is sobering. In the case of New Zealand, the Press Council sought an independent review of its objectives, structure and performance - the first such inquiry in more than 30 years. The review was generally supported by the media industry and concluded that the Council had been performing 'generally usefully' since it was established. Its recommendations were designed to strengthen the institution of democracy: 'We hope our suggestions result in a robust Press Council that can adapt to change, even turmoil, that all types of media are presently experiencing, largely as a consequence of the arrival of the digitally based technologies' (Barker \& Evans, 2007, p. 84).

In the case of post-coup and pre-censorship Fiji, the media review was instigated by a statutory body that had lost the confidence and trust of news organisations themselves, was carried out by a consultant whose credibility was seriously challenged and with a flawed methodology. The final recommendations were generally perceived as draconian, unworkable and intended to compromise an independent media. Lost in the debate, which degenerated into defensive hyperbole and personal insults, was any serious industry acknowledgment that the Fiji media does have shortcomings (Shameem, 2008c; Singh, S., 2008; Singh, T. R., 2008) and that an empirical strategic review would help chart a more constructive course for the future. Beneath the emotive language and invective, much of the Anthony report echoed media weaknesses identified by the Thomson Foundation review more than a decade earlier. In that 1996 report, some media problems such as poor standards and lack of ethics were blamed on an exodus of qualified and experienced journalists after the Rabuka coups. Three further coups and the evolution of a coup culture since then have accentuated the problems. 


\section{Notes}

1. Fiji Sun publisher Russell Hunter, an Australian citizen, was expelled from Fiji on 27 February 2008 because he was alleged by the regime as 'conducting himself in a manner prejudicial to the peace, defence, public safety, security and stability of the sovereign state of the Fiji Islands' (Fiji government media release, 27 February 2008). Hunter was deported after publishing a series of investigative articles by Victor Lal about Interim Finance Minister Mahendra Chaudhry, alleging taxation irregularities and secret offshore accounts. Chaudhry was cleared by a government taxation inquiry. In 1999, Hunter had been refused an extension of his work permit as editor-in-chief of The Fiji Times by Chaudhry's Labour Party-led coalition government. However, this was later overturned by the post-coup Laisenia Qarase government. Hunter and Lal were jointly awarded the prize for outstanding journalism at the 2008 Fiji Awards for Media Excellence (FAME). On 2 May 2008 — on the eve of the UNESCO World Media Freedom Day-Evan Hannah, also an Australian and publisher of The Fiji Times, was deported and put on a flight to Korea in spite of an injunction against his expulsion. The man who replaced him, Rex Gardner, was expelled on 26 January 2009 after The Fiji Times pleaded guilty and was fined FJD\$100,000 for publishing a defamatory letter about the Fiji High Court judiciary.

2. In the preface to the James Anthony report (Fiji Human Rights Commission, 2008), FHRC director Dr Shaista Shameem (2008a) claimed that New Zealand journalist Michael Field had intervened and pressured the original choice as consultant, former New Zealand Race Relations Conciliator Gregory Fortuin, to stand down from the inquiry. According to Shameem:

Mr Fortuin informed the commission that ... journalist Michael Field telephoned him to tell him that he (Fortuin) would be lending "credibility to the discredited Human Rights Commission director and coup apologist' and that he would 'be manipulated by the director for her own purposes'. Mr Fortuin reported that Field and 'two lawyers' from Fiji told him that the report of the commission 'had already been written' but that it 'needs a credible person to publish it'.

Such deliberate obstruction of the FHRC by Michael Field can be dealt with pursuant to 447 of the Human Rights Commission Act, which prohibits anyone from wilfully hindering the commission's work. (Shameem, 2008a, p. 1)

Shameem (2008b) later wrote a bitter attack on Field's integrity in the Fiji Daily Post, describing a Broadcasting Standards Authority (2008) ruling against Radio New Zealand National for inaccurate statements made by him in an on-air commentary as a 'death knell'. Field (2008) replied on his own website, condemning the Fiji government's 'hack spin doctor'.

Another New Zealand journalist was also named in the preface to the report: David Robie (ibid., p. 1): 'The FHRC was also sent critiques of the Fiji media landscape authored by a NZ journalist who had previously held the prestigious position of head of the University of the South Pacific's Journalism School.' To clarify this statement, this author had no connection with the FHRC review and the critique referred to was 


\section{PUBLIC RIGHT TO KNOW}

a peer-reviewed academic article in the public domain (see Robie, 2001).

3. Bertrand developed the term $M * A * S$ (media accountability systems), or $M * A * R * S$ in French for Moyens d'assurer la responsibilite sociale des medias (means to insure that media will be socially responsible. In his 2003 book An Arsenal for Democracy: Media accountability systems (p. 17), he defined $\mathrm{M}^{*} \mathrm{~A}^{*} \mathrm{~S}$ as any means of improving media services to the public that function independently from the government:

[They] are expected to achieve their purpose by increasing the competence of journalists; by discovering (through observation and analysis) what media do and don't do, as compared to what they should do. And, mainly, $M^{*} \mathrm{~A} * \mathrm{~S}$ enable media to hear the consumers' views, what they like, dislike, might like. And they enable media to discover, correct, explain their errors and mistakes, and apologise for them. $\mathrm{M}^{*} \mathrm{~A} * \mathrm{~S}$ are a mix of quality control, customer service, continuing education - and much more, certainly not just self-regulation. To the citizens, $\mathrm{M}^{*} \mathrm{~A} * \mathrm{~S}$ give back human rights that a media caste is inclined to confiscate.

4. Fiji Television, Fiji Times, Fiji Sun, Fiji Broadcasting Corporation Ltd and Communications Fiji Ltd (FHRC, 2008, Appendix 7).

\section{References}

Anthony, J. (2008, August 22). Lessons from the past. Fiji Daily Post, republished by Pacific Media Watch. Retrieved on 26 September 2008, from http://kauri.aut.ac.nz:8080/dspace/handle/123456789/1389

Barker, I., and Evans, L. (2007). Review of the New Zealand Press Council. Wellington: Newspaper Publishers Association, Engineering, Printing and Manufacturing Union (EPMU), and Magazine Publishers Association. Retrieved on 26 September 2008, from www.presscouncil.org.nz/articles/press_council_review.pdf

Bertrand, C.-J. (2005). Introduction: Media accountability. Pacific Journalism Review, 11(2), 5-16.

Bertrand, C.-J. (ed.) (2003). An arsenal for democracy: Media accountability systems. Cresskill, NJ: Hampton Press Inc.

Bertrand, C.-J. (2002). Media ethics and accountability systems. New Brunswick, NJ; London: Transaction Publishers.

Bromley, M. (2003). $\mathrm{M}^{*} \mathrm{~A} * \mathrm{~S}$ in the United Kingdom. In C.-J. Bertrand (Ed.). An Arsenal for Democracy: Media accountability systems (pp. 307-322). Cresskill, NJ: Hampton Press Inc.

Cass, P. (2004). Media ownership in the Pacific: Inherited colonial commercial model but remarkably diverse. Pacific Journalism Review, 10(2), 82-110.

Communications Fiji Ltd (2007). Response to the Fiji Human Rights Commission media report [Letter]. October 9.

Dadge, D. (ed.) (2005) Silenced: International journalists expose media censorship. New York: Prometheus Books.

Davis, G. (2008, March 4). Wrong man for the wrong job. The Fiji Times, p. 9. Retrieved 26 September 2008, from www.fijitimes.com/story.aspx?id=82956 
Du Fresne, K. (2005). The right to know: News media freedom in New Zealand. Wellington: Newspaper Publishers Association.

Ellis, G. (2005). Different strokes for different folks: Regulatory distinctions in New Zealand media. Pacific Journalism Review, 11(2): 63-83.

Elsaka, N. (2004). Beyond consensus? New Zealand journalists and the appeal of 'professionalism' as a model for reform. Unpublished $\mathrm{PhD}$ thesis. Christchurch: University of Canterbury.

Field, M. (2008, September 16). Standards body slams Field. Retrieved on 26 September 2008, from www.michaelfield.org/BSA.htm

Field, M. (2007). The media and the spectre of the 2000 coup. In J. Fraenkel and S. Firth (Eds.), From election to coup in Fiji: The 2006 campaign and its aftermath (pp. 174-184). Canberra: Australian National University.

Fiji Government media release (2008, February 27). Press conference by the Minister of Defence, National Security and Immigration, Ratu Epeli Ganilau. Retrieved on 11 October 2008, from www.fiji.gov.fj/punblish/page_11297.shtml

Fiji Government media release (2008, July 17). Government to formulate media legislation. Retrieved on 26 September 2008, from www.fiji.gov.fj/publish/ page_12360.shtml

Fiji Government media release (2008, November 4). Media promulgation in progress: Leweni. Retrieved on 5 November 2008, from www.fiji.gov.fj/publish/page_13362. shtml

Fiji Human Rights Commission [FHRC] (2007). Special investigations report: Australian intervention in Fiji in October-November 2006-an issue of international law. Suva, March 31.

Fiji Human Rights Commission [FHRC] (2008). Freedom and independence of the media in Fiji: A report [James Anthony report]. Retrieved on 21 April 2008, from http://kauri.aut.ac.nz:8080/dspace/bitstream/123456789/79/1/fhrcmediarpt2007. pdf

Fiji Media Council (2008). About [FMC], retrieved on 26 September 2008, from www.fijimediacouncil.org

Fiji State of the Nation Report (2008). 4.1 The role of the media. Suva: National Council for Building a Better Fiji (NCBBF).

Fiji Sun (2008, July 18). Another threat to media freedom [Editorial]. Retrieved on 26 September 2008, from www.sun.com.fj/mews_main/in_search.asp\#

Fiji Sun (2007, August 7). Source of mystery [Editorial]. Retrieved on 26 September 2008, from www.sun.com.fj/mews_main/in_search.asp\#

Fiji Times Limited. (2007). Response to Fiji Human Rights Commission media inquiry report. October 12 .

Fiji Television Limited. (2007). Response by Fiji Television Limited to the Fiji Human Right Commission's inquiry report into the freedom and independence of Fiji's media: A (dis)hornet's nest indeed! October 10.

Fraenkel, J., and Firth, S. (Eds.). (2007). From election to coup in Fiji: The 2006 campaign and its aftermath. Canberra: Australian National University. 


\section{PUBLIC RIGHT TO KNOW}

Herman, J., Siwatibau, S., and Sweetman, B. (2009). Free and responsible: Towards a more effective Fiji media council. Report of the 2009 review. Suva: Fiji Media Council.

Hunter, R. (2007a). Letter to the Fiji Human Rights Commission Director. August 2.

Hunter, R. (2007b). Letter to the Fiji Human Rights Commission Director: Media inquiry report. October 9.

Islands Business International (2007). [Response to the Fiji Human Rights Commission media report.] October 4.

Jeffries, J. (2002). Establishing a code of ethics. Paper presented at the Asia-Pacific Regional Press Freedom seminar.

Karlekar, K. and Marchant, E. (2008). Freedom of the press 2007: a global survey of media independence. New York: Freedom House; Lanham, MA; Plymouth, UK: Rowman \& Littlefield.

McDonald, Ross G. (2007). Letter to the Fiji Human Rights Commission Director. October 9.

Media Council Fiji Ltd (2007). [Responding to the Fiji Human Rights Commission media report.] October 26.

Mediawatch (2001, July 8). Report: Pacific Island journalism. Radio New Zealand. Retrieved on 22 November 2006, from www.mediawatch.co.nz/default,322.sm

Mediawatch (2008, July 6). Newspapers downsized and centralised. Radio New Zealand. Retrieved on 26 September 2008, from www.radionz.co.nz/national/ programmes/mediawatch/programme_archive

Moore, P. (2008). Media and the people's charter. Suva: National Council for Building a Better Fiji.

Morgan, K. (2003). Council into commission. In C-J. Bertrand (Ed.), An arsenal for democracy: Media accountability systems (pp. 137-146). Cresskill, NJ: Hampton Press Inc.

Morgan, K. (1998). Draft codes of ethics and practice for the Fiji media council. Consultancy report. Cardiff: The Thomson Foundation.

Morgan, K., and Thomas, J. P. (1996). Future media legislation and regulation for the republic of the Fiji Islands. [Consultancy report.] Cardiff: The Thomson Foundation.

National Task Team 1 on Good Governance (n.d.). Background paper: The role of the media in a democratic Fiji Islands. National Council for Building a Better Fiji.

NZ Broadcasting Standards Authority (2008, August 27). BSA Decision No: 2008-040: Complainant: C. T. Pryde, Solicitor-General of the Republic of the Fiji Islands; Broadcaster Radio New Zealand Ltd, broadcasting as Radio New Zealand National. Retrieved on 26 September 2008, from http://kauri.aut.ac.nz:8080/dspace/ handle/123456789/1463

Parkinson, W., Hannah, E., Nawari, M. and Hunter, R. (2007). Re: Human Rights Commission inquiry into freedom and independence of the media. July 27.

Pearson, M. (2007). The journalist's guide to media law: Dealing with legal and ethical issues (3rd ed.). Crows Nest, NSW: Allen \& Unwin. 
Price, S. (2007). Media Minefield. Wellington: NZ Journalists Training Organisation.

Public member appointment (2008, October 4). [Press Council advertisement]. New Zealand Herald, p. A15.

Qarase and others vs Bainimarama and others (2008). HBC60.07S, HBC398. Retrieved on 10 October 2008, from http://kauri.aut.ac.nz:8080/dspace/ handle/123456789/1545

Rankine, J., Nairn, R., Moewaka Barnes, A., Gregory, M., Kaiwai, H.; Borell, B. and McCreanor, T. (2007). Media and te tiriti o Waitangi 2007. Kupu Taea, Auckland.

Ratuva, S. (2008, October 3). Multiple battle lines-who is winning? Pacific Media Centre Online. Retrieved on 4 October 2008, from www.pmc.aut.ac.nz/postmortem/081003_Fiji-Ratuva.shtml

Reporters sans frontières (2008, July 18). Fiji's proposed new media law threatens press freedom. Retrieved on 26 February 2008, from www.rsf.org/Proposed-lawthreatens-press.html

Richstad, J. (2003). Right to communicate in the internet age. In C.-J. Bertrand (Ed.), An arsenal for democracy: Media accountability systems (pp. 35-48). Cresskill, NJ: Hampton Press Inc.

Robie, D. (2009). 'Sulu censors' stifle Fiji news media in regime crackdown, Pacific Media Centre. Retrieved on 30 May 2009, from http://pacificmediacentre.blogspot. com/2009/04/sulu-censors-stifle-fiji-news-media-in.html

Robie, D. (2008). South Pacific notions of the Fourth Estate: A collision of media models, culture and values. In E. Papoutsaki and U. S. Harris (Eds.), South Pacific islands communication (pp. 102-116). Singapore: Asian Media Information and Communication Centre (AMIC); Suva: University of the South Pacific; and Auckland: Pacific Media Centre.

Robie, D. (2005). Campaigning with passion for an 'arsenal for democracy'. Pacific Journalism Review, 11(2), 245-249.

Robie, D. (2004). Mekim nius: South Pacific media, politics and education. Suva: University of the South Pacific Book Centre.

Robie, D. (2003). Pacific media councils and cultural values: Safety valve or entrenched hegemony? Pacific Journalism Review, 9, 102-122.

Robie, D. (2001). Coup coup land: The press and the putsch in Fiji. Asia Pacific Media Educator, 10, 141-162.

Robie, D. (1999). Papua New Guinea. In Martin, R. (Ed.), Speaking freely: Expression and the law in the Commonwealth (pp. 489-518). Toronto: Commonwealth Association for Education in Journalism and Communication, and Irwin Law.

Robie, D. (1989). Blood on their banner: Nationalist struggles in the South Pacific. London: Zed Books.

Rosenberg, B. (2008). NZ media 2007: The year of the accountant. Pacific Journalism Review. 14(1), 176-213. 


\section{PUBLIC RIGHT TO KNOW}

Shameem, S. (2008a). Preface. In Fiji Human Rights Commission, Freedom and independence of the media in Fiji: A report [James Anthony report]. Retrieved on 21 April 2008, from http://kauri.aut.ac.nz:8080/dspace/handle/123456789/79

Shameem, S. (2008b, September 17). Michael Field: The writing on the wall. Fiji Daily Post. Retrieved on 26 September 2008, from http://fijidailypost.com/opinion. php?date $=20080917$

Shameem, S. (2008c). Human rights, development and freedom of information: Media responsibility. In S. Singh and B. Prasad, (Eds.), Media and development: issues and challenges in the Pacific Islands (pp. 137-147). Lautoka: Fiji Institute of Applied Studies and Auckland: Pacific Media Centre.

Singh, S. (2008, August 1). A history of failed bids to muzzle the media. Pacific Media Centre Online. Retrieved on 26 August 2008, from www.pmc.aut.ac.nz/niusbeat/080801_Fijipressure.shtml

Singh, S. (2005). Six Oceania microstates: The genesis of media accountability. Pacific Journalism Review, 11(2), 42-60.

Singh, T. R. (2008, September 27). Media under scrutiny. The Fiji Times. Retrieved on 28 September 2008, from www.fijitimes.com/story.aspx?id=101976

Sun (Fiji) News Ltd (2007) [Response to the Fiji Human Rights Commission media report.] October 4.

Tarte, D. (2007). Letter from the Fiji Media Council to the FHRC. August 1.

Dr David Robie is an associate professor in journalism and director of the Pacific Media Centre in the School of Communication Studies at New Zealand's AUT University. He is also a former coordinator of the regional journalism programme at the University of the South Pacific in Fiji. An earlier version of this paper under the original title 'Freedom of the gatekeepers: A Fiji and NZ media case study-self-regulation vs state intervention'was presented at the Public Right to Know (PR2K7) conference at the University of Technology, Sydney, 17-18 October 2008.

david.robie@aut.ac.nz 